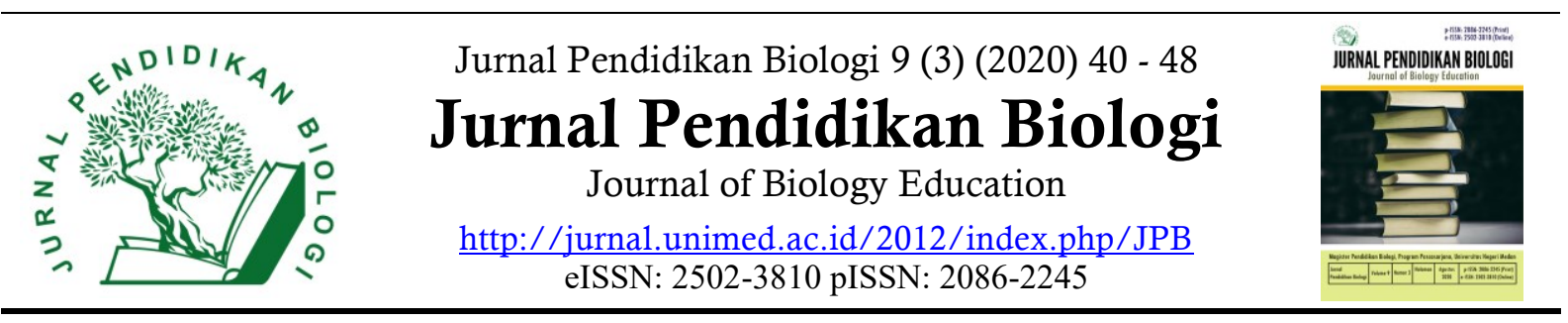

\title{
Peningkatan Minat dan Hasil Belajar IPA Melalui Metode Eksperimen Pada Materi Rangkaian Listrik di Kelas IX SMPN 1 Percut Sei Tuan
}

\author{
Syofia Yohana \\ Sekolah Menengah Pertama Negeri 1 Percut Sei Tuan, Jalan Besar Tembung Gang Pendidikan Kabupaten Deli \\ Serdang, Sumatera Utara, Indonesia
}

\section{INFO ARTIKEL}

\section{Histori Artikel}

Received 9 September 2020

Revised 10 Nopember 2020

Accepted 20 Nopember 2020

Published 28 Desember 2020

\author{
Keywords: \\ Learning Outcomes, \\ Experimental Methods, \\ Electrical Circuits
}

\begin{abstract}
This research was conducted on the basis of the results of observations of the science learning process in class, where the interests and learning outcomes of science learning, especially in class IX-3 have not progressed as expected. Low learning interest causes the students' daily test scores to show disappointing results, where the results have not reached the expected Minimum Completeness Criteria standard. The average value of science learning outcomes in grades IX -3 at SMP Percut Sei Tuan only reached 55.1. To overcome this problem, it is necessary to improve by conducting Classroom Action Research. Action research was conducted in class IX-3 SMP Negeri 1 Percut Sei Tuan Jln.Besar Tembung Gang Pendidikan, Percut Sei Tuan District, Deli Serdang Regency. The research lasted for 3 months in the odd semester of the 2017/2018 school year which was carried out in 2 cycles by suggesting 4 stages for each cycle, namely: the planning, implementation, observation and reflection stages. The data obtained from each cycle were analyzed using qualitative and quantitative data analysis. This can be seen from the results of the average observation of student interest in learning science per individual, where students with very high interest in learning are $3.13 \%$, students with high interest categories are $46.87 \%$, students who are interested in learning are $34.37 \%$ and students with low interest in learning are $15.63 \%$. Overall, the percentage of interest in learning has not reached $75 \%$. Then continued with the second cycle, it was obtained that the observation interest in learning had increased. This was seen from the results of the average observation of student interest in learning science per individual that had increased. where students with very high interest in learning categories $25 \%$ of students with high interest categories $66.67 \%$, students with sufficient interest in learning categories $8.33 \%$ overall the percentage of interest in learning has reached above $75 \%$. The results of the first cycle test, there were 24 students $(66.67 \%)$ who had achieved mastery learning while 12 students $(33.33 \%)$ had not yet achieved mastery learning. After it is known that there is an increase, it is continued to provide action in cycle II. The results of the second cycle test had increased, the number of students who completed was very large, namely from 36 students, it turned out that 33 students (91.67\%) had achieved completeness in learning, only 3 students $(8.33 \%)$ had not achieved completeness in study.
\end{abstract}

Copyright (C) 2021 Universitas Negeri Medan. Artikel Open Access dibawah lisensi CC-BY-4.0 (https://creativecommons.org/licenses/by/4.0) 


\section{How to Cite}

Yohana, S. (2020). Peningkatan Minat dan Hasil Belajar IPA Melalui Metode Eksperimen Pada Materi Rangkaian Listrik di Kelas IX SMPN 1 Percut Sei Tuan. Jurnal Pendidikan Biologi, 9(3), 40-48.

\section{PENDAHULUAN}

Pada jenjang Sekolah Menengah Pertama (SMP), mata pelajaran Ilmu Pengetahuan Alam (IPA), merupakan mata pelajaran yang berfungsi untuk memperluas wawasan pengetahuan tentang materi dan energi, meningkatkan ketrampilan ilmiah, menumbuhkan sikap ilmiah dan kebesaran/ kepedulian pada produk teknologi melalui penerapan teori/prinsip fisika yang sudah dikuasai sebelumnya, serta kesadaran pada kebesaran Tuhan Yang Maha Esa.

Depdiknas (2006) menerangkan bahwa: "IPA berhubungan dengan cara mencari tahu tentang alam secara sistematis sehingga IPA bukan hanya penguasaan kumpulan pengetahuan yang berupa fakta-fakta, konsep-kosep atau prinsip saja tetapi juga merupakan suatu proses penemuan. Pendidikan IPA diharapkan menjadi wahana bagi peserta didik untuk mempelajari diri sendiri dan alam sekitar serta prospek pengembangan lebih lanjut dalam menerapkannya dalam kehidupan sehari-hari. Proses pembelajaran menekankan pada pemberian pengalaman langsung untuk mengembangkan kompetensi agar menjelajahi dan memahami alam sekitar secara ilmiah. Pendidikan IPA diarahkan untuk penemuan dan berbuat sehingga dapat membantu peserta didik untuk memperoleh pengalaman yang lebih mendalam tentang alam sekitar".

Pembuktian dan pengalaman nyata dalam belajar tersebut kurang efektif bila dilakukan dengan pendekatan ekspositorik seperti yang selama ini sering dilakukan guru. Untuk itu dibutuhkan metode yang tepat dalam memperoleh pengalaman nyata tersebut. Salah satu metode yang dapat digunakan untuk pemerolehan pengalaman belajar yang nyata bagi siswa adalah metode eksperimen. Menurut Hermawan (2007) metode eksperimen adalah suatu cara penyajian pelajaran dimana siswa melakukan percobaan dengan mengalami dan membuktikan sendiri sesuatu yang dipelajari. Karena metode eksperimen sebagai suatu metode pengembangan ilmu akan mampu merangsang sikap ilmiah siswa melalui percobaan sendiri secara sederhana, dan membuktikan kebenaran kata-kata yang selama ini diketahuinya tapi kurang difahami maknanya.

Kemampuan guru dalam merancang strategi, metode, dan media mutlak dibutuhkan. Tidak semua metode cocok untuk sebuah pembelajaran. Ada metode yang cocok dengan pembelajaran tertentu, dan ada pula yang kurang sesuai. Sebagaimana dipertegas oleh Wina (2008), "keberhasilan implementasi strategi pembelajaran sangat tergantung pada cara guru menggunakan metode pembelajaran". Pembelajaran IPA dengan menyertakan strategi, metode, dan media yang tepat akan menumbuhkan minat siswa untuk pembelajaran IPA yang dilaksanakan.

Namun pengalaman penulis di lapangan, khususnya siswa di kelas IX -3 SMP Percut Sei Tuan menunjukkan kurang memperlihatkan rasa ketertarikan terhadap materi pembelajaran Ilmu Pengetahuan Alam karena tidak melihat secara nyata konsep-konsep yang diajarkan. Siswa kurang melihat hubungan antara materi IPA dengan kehidupannya sehari-hari, sehingga siswa kurang berminat untuk mempelajari IPA dan pada akhirnya nilai-nilai Ulangan Harian siswa menunjukkan pencapaian hasil yang mengecewakan, karena belum mencapai standar Kriteria Ketuntasan Minimal yang diharapkan. Nilai rata-rata hasil pembelajaran IPA di kelas kelas IX -3 SMP Percut Sei 
Tuan hanya mencapai 55,1. Paling rendah bila dibandingkan dengan mata pelajaran lain.

Rendahnya hasil belajar tersebut setelah ditelusuri antara lain disebabkan oleh beberapa faktor. Faktor dari guru, kurang bervariasi dalam penggunaan metode karena minimnya peralatan, dan terlalu sering menggunakan metode ceramah dan tanya jawab saja. Sedangkan faktor dari siswa, kurang melakukan eksperimen yang memadai untuk Kompetensi Dasar yang membutuhkan penalaran dan pembuktian konsep/teori karena kurang tersedianya peralatan eksperimen di sekolah. Akibatnya guru menyampaikan pembelajaran lebih banyak dengan pendekatan ekspositoris, sedangkan siswa hanya dijejali dengan konsep-konsep saja tanpa praktikum. Hal ini menjadikan siswa kesulitan menguasai materi IPA karena pembelajaran yang dilakukan belum mengakomodir secara optimal kebutuhan tersebut.

Pada umumnya materi pembelajaran IPA membutuhkan pembuktian dan pengalaman nyata bagi siswa dalam mempelajarinya. Pembuktian dan pengalaman nyata dalam belajar tersebut kurang efektif bila dilakukan dengan pendekatan ekspositorik seperti yang selama ini sering dilakukan guru. Untuk itu dibutuhkan metode yang tepat dalam memperoleh pengalaman nyata tersebut. Salah satu metode yang dapat digunakan untuk pemerolehan pengalaman belajar yang nyata bagi siswa adalah metode eksperimen. Karena metode eksperimen sebagai suatu metode pengembangan ilmu akan mampu merangsang sikap ilmiah siswa melalui percobaan sendiri secara sederhana, dan membuktikan kebenaran kata-kata yang selama ini diketahuinya tapi kurang difahami maknanya. Penggunaan metode eksperimen diharapkan mampu menumbuhkan rasionalitas siswa dalam berpikir dan bertindak, tidak hanya menerima pendapat orang lain. Siswa diharapkan mampu mengembangkan kepedulian terhadap perkembangan Ilmu Pengetahuan. Penggunaan metode eksperimen yang memberikan pembuktian dan pengalaman nyata bagi siswa dalam pembelajaran IPA merupakan salah satu solusi yang diharapkan dapat meningkatkan hasil pembelajaran IPA.

Berdasarkan masalah tersebut, maka penulis melakukan perbaikan pembelajaran melalui Penelitian Tindakan Kelas (PTK) dengan rincian dua siklus untuk mata pelajaran IPA. Sesuai dengan kurikulum 2004, penyampaian bahan kajian materi pelajaran IPA pada umumnya tidak dapat terlepas dari kegiatan praktikum. Kegiatan praktikum dapat memberikan pengaruh yang positif terhadap penguasaan konsep, karena ada keterkaitan antara teori dan praktikum. Praktikum dapat memberikan penguatan terhadap penguasaan konsep, dan teori yang disampaikan dalam pembelajaran dapat diuji dengan praktikum, sehingga siswa lebih memahami konsep yang disampaikan. Menurut Rustaman (2002), terdapat beberapa alasan dilakukannya kegiatan praktikum, yaitu: pertama, praktikum membangkitkan motivasi belajar sains. Kedua, praktikum mengembangkan keterampilanketerampilan dasar melaksanakan eksperimen. Ketiga, praktikum menjadi wahana belajar pendekatan ilmiah, dan keempat, praktikum menunjang pemahaman materi pelajaran.

Agar pembelajaran IPA lebih bermakna, pembelajarannya harus banyak didukung oleh praktikum, tetapi praktikum yang tidak disertai oleh penilaian ternyata juga kurang mendorong siswa melakukannya dengan sungguhsungguh. Oleh sebab itu perlu dilakukan penilaian terhadap kinerja siswa pada saat praktikum, hal ini sesuai dengan hasil penelitian Mahmudah (2000) bahwa penerapan penilaian kinerja dapat memotivasi siswa untuk melakukan kegiatan lebih sungguh-sungguh, dapat melatih siswa lebih mandiri, jujur, dan bertanggungjawab. 
Untuk mengetahui tingkat ketercapaian tujuan pembelajaran, diperlukan adanya suatu penilaian yang menyangkut segala aspek kegiatan belajar mengajar, yakni aspek kognitif, aspek afektif, dan aspek psikomotor. Hal ini berarti untuk mengukur pencapaian hasil belajar siswa tidak cukup hanya menggunakan tes tertulis (paper and pencil test) saja. Sesuai dengan tujuan evaluasi bidang pendidikan yaitu untuk meningkatkan kinerja individu atau lembaga (Dirjen Dikdasmen, 2004), maka evaluasi hasil belajar yang dalam pelaksanaannya didahului dengan asesmen harus mampu mendorong siswa untuk belajar lebih baik.

Berdasarkan latar belakang tersebut, penulis bermaksud melakukan penelitian yang berkaitan dengan pembelajaran yang hubungan dengan minat belajar dan pemahaman konsep siswa terhadap rangkaian listrik. Siswa dikelas IX-3 SMP Negeri 1 Percut Se Tuan dalam proses pembelajaran IPA masih kurang termotivasi, masing kurang minat terhadap ilmu pengetahuan alam, khususnya materi rangkaian listrik dalam pembelajaran IPA, sehingga hasil belajar siswa dikelas IX-3 pada pelajaran IPA masih rendah. Dan ini menjadi masalah bagi saya, sebagai guru yang mengajar bidang study IPA tersebut.

Hasil diskusi dengan teman sejawat sesama guru IPA SMP Negeri 1 Percut Sei Tuan perlu adanya Penelitian Tindakan Kelas guna meningkatkan minat belajar dan hasil belajar siswa kelas IX-3. Penelitian yang dilakukan diharapkan akan memberikan kontribusi yang baik terhadap pendidikan di SMP Negeri 1 Percut Sei Tuan.

\section{METODE}

Penelitian Tindakan Kelas ini dilaksanakan di Kelas IX-3 SMP Negeri 1 Percut Sei Kecamatan Percut Sei Tuan kabupaten Deli Serdang, provinsi Sumatera
Utara. Penelitian ini berlangsung selama 3 bulan di semester ganjil yang dilaksanakan sebanyak 2 siklus. Subjek dalam penelitian ini adalah siswa kelas IX-3 yang berjumlah 36 orang siswa, terdiri atas laki-laki 15 dan perempuan 21. Pemilihan siswa kelas IX-3 sebagai subjek penelitian karena peneliti mengajar di kelas tersebut dan tingkat pencapaian hasil belajar masih banyak yang belum mencapai ketuntasan belajar sesuai dengan KKM. Desain penelitian yang digunakan berbentuk siklus yang mendaur ulang empat kegiatan pokok yang berupa perencanaan, pelaksanaan, pengamatan, dan refleksi. Dengan mendaur ulang empat kegiatan pokok ini dapat menemukan suatu masalah dan dicarikan solusi yang berupa perencanaan perbaikan, pelaksanaan tindakan yang telah direncanakan dengan disertai kegiatan observasi, lalu direfleksikan sehingga menghasilkan tindakan berikutnya.Tahapan ini akan berulang dilakukan pada setiap siklus selama 2 siklus yang direncanakan untuk dilaksanakan. Pengumpulan data dilakukan dalam dua tahap yaitu; tahap pertama mengumpulkan data hasil pengamatan terhadap minat belajar siswa dan yang kedua hasil belajar siswa.

Data pada penelitian ini dianalisis untuk mengetahui tingkat minat belajar siswa dan peningkatan hasil belajar siswa pada materi rangkaian listrik dengan menggunakan metode eksperimen. Data yang diperoleh dari setiap siklus yang dilaksanakan dianalisis secara deskriptif dengan menggunakan teknik persentase untuk melihat tingkat kecenderungan yang terjadi pada setiap kegiatan pembelajaran yang dilakukan. Peningkatan hasil belajar siswa dapat diukur ketuntasannya berdasarkan KKM yang sudah ditetapkan. Tingkat keberhasilan siswa diperoleh dari ratarata berdasarkan persentase. 


\section{HASIL DAN PEMBAHASAN}

Hasil penelitian dari proses pembelajaran tindakan kelas melalui metode eksperimen diperoleh hasil pengamatan yang dilakukan oleh pengamat pada siklus I terhadap minat belajar siswa pada materi rangkaian listrik yang disajikan pada Tabel 1 berikut ini.

Tabel 1. Data Minat Belajar Siswa pada Siklus I

\begin{tabular}{llll}
\hline No & Aspek yang diobservasi & Jumlah Skor & Persentase \\
\hline 1 & Perasaan Senang Terhadapan Pelajaran dalam metode & 58 & $80,55 \%$ \\
& eksperimen & 57 & $79,16 \%$ \\
2 & Siswa yang perhatian dalam belajar & 27 & $37,50 \%$ \\
3 & Siswa yang tekun mengerjakan tugas & 33 & $45,83 \%$ \\
4 & Siswa yang aktif dalam kegiatan belajar & $68,55 \%$ \\
5 & Siswa yang senang dengan nilai tugas yang diperolehnya & 49 & $62,31 \%$ \\
\hline
\end{tabular}

Berdasarkan Tabel 1 di atas, persentase minat belajar dengan metode eksperimen belum mencapai hasil yang diharapkan. Hal ini dilihat dari rata-rata minat belajar dengan metode eksperimen siswa secara keseluruhan belum mencapai $75 \%$. Persentase indikator minat belajar dengan metode eksperimen yang terlihat masih kurang, data observasi Perasaan Senang Terhadapan Pelajaran dalam metode eksperimen $(80,55 \%)$, Siswa yang perhatian dalam belajar $(79,16 \%)$, Siswa yang tekun mengerjakan tugas $(37,50)$, Siswa yang aktif dalam kegiatan belajar jumlah (45,83\%), siswa yang senang dengan nilai tugas yang diperolehnya jumlah $(68,55)$. Hal ini disebabkan siswa masih kurang berminat dalam melakukan praktikum rangkaian listik. Selain itu juga terdapat siswa yang mendominasi kegiatan dalam pembelajaran sehingga siswa yang lain tidak mendapat kesempatan untuk melakukan eksperimen sesuai dengan yang diharapkan. Berdasarkan hasil analisis data hasil observasi didapatkan data persentase minat belajar dengan metode eksperimen secara individu. Hal ini disajikan dalam Tabel 2.
Tabel 2. Data Persentase Minat Belajar IPA Siswa Per Individu Siklus I Berdasarkan Observasi

\begin{tabular}{cccc}
\hline No & Kategori Aktivitas & $\begin{array}{c}\text { Jumlah } \\
\text { Siswa }\end{array}$ & Persentase \\
\hline 1 & Sangat Tinggi & 1 & $3,13 \%$ \\
2 & Tinggi & 15 & $46,87 \%$ \\
3 & Cukup & 11 & $34,37 \%$ \\
4 & Rendah & 5 & $15,63 \%$ \\
5 & Sangat Rendah & 0 & $0 \%$ \\
\hline
\end{tabular}

Sumber: Data primer yang diolah

Dari tes hasil belajar siswa pada kondisi awal sebelum dilakukan pembelajaran tindakan kelas melalui metode eksperimen nilai yang peroleh siswa sangat rendah. Pencapaian ketuntasan belajar masih termasuk kategori sangat kurang. Dari 36 orang siswa yang menjadi subjek dalam penelitian ini, ternyata hanya 3 orang siswa $(8,33 \%)$ yang sudah mencapai ketuntasan belajar materi rangkaian listrik, sedangkan 33 orang siswa $(91,67 \%)$ belum mencapai ketuntasan dalam belajar. Disajikan dalam bentuk Tabel 3. 
Tabel 3. Data Hasil Tes Awal

\begin{tabular}{|c|c|c|c|c|}
\hline No & $\begin{array}{l}\text { Hasil } \\
\text { Tes }\end{array}$ & Keterangan & $\begin{array}{c}\text { Jumlah } \\
\text { Siswa } \\
\end{array}$ & Persentase \\
\hline 1 & $\begin{array}{l}\text { Skor } \\
70\end{array}$ & Tuntas & 3 & $8,33 \%$ \\
\hline 2 & Skor & $\begin{array}{l}\text { Tidak } \\
\text { Tuntas }\end{array}$ & 33 & $91,67 \%$ \\
\hline \multicolumn{2}{|c|}{ Jumlah } & & 36 & $100 \%$ \\
\hline
\end{tabular}

Setelah dilaksanakan tindakan pada siklus I terdapat peningkatan hasil belajar siswa bila dibanding dengan hasil tes awal. Untuk lebih jelas mengenai persentase ketuntasan belajar siklus I dapat dilihat pada Tabel 4 berikut.

Tabel 4 Data Hasil Tes Siklus I

\begin{tabular}{lcccc}
\hline No & $\begin{array}{l}\text { Hasil } \\
\text { Tes }\end{array}$ & Keterangan & $\begin{array}{l}\text { Jumlah } \\
\text { Siswa }\end{array}$ & Persentase \\
\hline 1 & Skor & Tuntas & 21 & $58,33 \%$ \\
2 & Skor & Tidak & 15 & $41,67 \%$ \\
\hline Jumlah & & 36 & $100 \%$ \\
\hline
\end{tabular}

Dengan memperhatikan Tabel 4 di atas dapat dilihat bahwa ada minat belajar siswa dengan penyampaian materi dengan menggunakan metode eksperimen ini dan hasil belajar pada materi Rangkaian listrik pada tes siklus I ternyata hasilnya lebih baik dari tes awal (pre-test) walaupun hasil nilai rata-rata yang diperoleh masih rendah tapi ada kenaikan yang signifikan, sehingga masih perlu dilanjutkan ke pelaksanaan siklus II.

Pada siklus II peneliti membuat alternatif pemecahan masalah minat belajar dan mengatasi kesulitan siswa dalam pembelajaran materi rangkaian listik, terutama tentang rangkian listrik seri dan paralel. Perencanaan ini dilakukan khususnya pada siswa yang minat belajarnya rendah dan nilai hasil belajarnya yang masih memperoleh nilai rendah.

Dari hasil pengamatan yang dilakukan oleh pengamat pada siklus II terhadap aktivitas siswa pada kegiatan pembelajaran dengan menggunakan metode eksperimen pada materi rangkaian listik. Berikut disajikan pada Tabel 5 dibawah ini.

Tabel 5. Data Minat Belajar Siswa pada Siklus II

\begin{tabular}{llcc}
\hline No & Aspek yang diobservasi & Jumlah Skor & Persentase \\
\hline 1 & Perasaan Senang Terhadapan Pelajaran dalam & 71 & $98,61 \%$ \\
& metode eksperimen & 67 & $91,66 \%$ \\
2 & Siswa yang perhatian dalam belajar & 41 & $56,94 \%$ \\
3 & Siswa yang tekun mengerjakan tugas & 51 & $70,83 \%$ \\
4 & Siswa yang aktif dalam kegiatan belajar & 45 & $62,50 \%$ \\
5 & Siswa yang senang dengan nilai tugas yang & 275 & $76,10 \%$ \\
\hline
\end{tabular}

Berdasarkan hasil analisis data hasil observasi didapatkan data persentase minat belajar dengan metode eksperimen secara individu. Hal ini disajikan dalam Tabel 6.
Tabel 6. Persentase Minat Belajar IPA Siswa Per Individu Siklus II Berdasarkan Observasi

\begin{tabular}{llcc}
\hline No & $\begin{array}{l}\text { Kategori } \\
\text { Aktivitas }\end{array}$ & $\begin{array}{l}\text { Jumlah } \\
\text { Siswa }\end{array}$ & Persentase \\
\hline 1 & Sangat Tinggi & 9 & $25,00 \%$ \\
2 & Tinggi & 24 & $66,67 \%$ \\
3 & cukup & 3 & $8,33 \%$ \\
\hline
\end{tabular}


Berdasarkan data pada Tabel 6 di atas, terlihat tingkat minat belajar siswa meningkat. Perasaan Senang Terhadapan Pelajaran dalam metode eksperimen sudah mencapai $98,61 \%$ Siswa yang perhatian dalam belajar juga sudah mencapai 91,66\%. Siswa yang tekun mengerjakan tugas $55,55 \%$, Siswa yang aktif dalam kegiatan belajar $54,17 \%$, dan Siswa yang senang dengan nilai tugas yang diperolehnya mencapai $62,50 \%$. Melalui metode eksperimen dengan menggunakan lembar pengamatan dan tes pada materi Rangkaian Listrik dalam mata pelajaran IPA dapat ditingkatkan hal ini dapat dilihat dari pelaksanaan setiap siklus. Siklus I dan Siklus II di peroleh hasil yang baik.

Berdasarkan hasil tes siklus II, dapat dilihat bahwa hasil belajar siswa dalam pembelajaran materi rangkaian listik ternyata telah cukup baik. Dengan memperhatikan data yang telah diperoleh dan dipaparkan dapat dilihat bahwa analisis hasil belajar materi rangkaian listik pada siswa kelas IX-3 pada siklus II ternyata hasilnya lebih baik dari siklus I, peningkatan ketuntasan belajar siswa telah cukup signifikan namun guru IPA akan terus memberikan bimbingan lanjutan.

Tabel 7. Data Hasil Tes Siklus II

\begin{tabular}{lllll}
\hline No & $\begin{array}{l}\text { Hasil } \\
\text { Tes }\end{array}$ & Keterangan & $\begin{array}{l}\text { Jumlah } \\
\text { Siswa }\end{array}$ & Persentase \\
\hline 1 & $\begin{array}{l}\text { Skor } \\
70\end{array}$ & $\begin{array}{l}\text { Tuntas } \\
2\end{array}$ & 33 & $(91,67 \%)$ \\
Skor & $\begin{array}{l}\text { Tidak } \\
\text { Tuntas }\end{array}$ & 3 & $(8,33 \%)$ \\
\hline Jumlah & & 36 & $100 \%$ \\
\hline
\end{tabular}

Berikut ini adalah deskripsi data yang diperoleh setelah melakukan penelitian tindakan kelas di SMP Negeri 1 Percut Sei Tuan TP.2017-2018 yang dimulai dari tes awal, tes siklus I dan tes siklus

Tabel 8. Deskripsi Data Hasil Belajar Kelas IX -3

\begin{tabular}{cccccc}
\hline No & Hasil Tes & $\begin{array}{c}\text { Jumlah Siswa } \\
\text { Yang Tuntas }\end{array}$ & Persentase & $\begin{array}{c}\text { Nilai Rata- } \\
\text { Rata }\end{array}$ & Keterangan \\
\hline 1 & Awal & 2 & $5,56 \%$ & 49,81 & Tidak Tuntas \\
2 & Siklus I & 23 & $63,89 \%$ & 74,62 & Tidak Tuntas \\
3 & Siklus II & 33 & $91,67 \%$ & 91,84 & Tuntas \\
\hline
\end{tabular}

Pada Kondisi Awal, siswa sangat sulit memahami materi rangkaian listrik karena mereka hanya mendapatkan penjelasan saja tanpa mempraktekkannya atau bereksperimen. Pengaruh bereksperimen pada materi rangkaian lisrik tersebut membuat siswa menarik mengikuti pembelajaran. Pada siklus I terlihat jelas peningkatan hasil belajar yang signifikan walaupun nilai ketuntasan 75 masih sedikit yang bisa mencapainya.

Hasil siklus I menunjukkan bahwa jumlah siswa yang sudah mencapai ketuntasan belajar masih rendah. Hal ini perlu dicermati peneliti, peneliti harus bisa memahami perbedaan tingkat pemahaman siswa. Analisis hasil belajar siswa pada siklus I masih lebih baik dari tes awal walaupun hasilnya belum maksimal, sehingga perlu dilanjutkan pada pelaksanaan siklus II, hal ini dapat dilihat dari kesulitan siswa dalam memahami materi rangkaian listrik.

Tes awal yang diberikan kepada siswa sebelum menentukan perencanaan sangat berguna untuk mengetahui perkembangan hasil belajar siswa sebelum diadakan pembelajaran dengan menggunakan metode eksperimen. Pelaksanaan tindakan pada siklus II dilakukan untuk mendapatkan hasil yang maksimal sehingga tercapai ketuntasan belajar yang lebih baik. Sebagai besar siswa belum mencapai ketuntasan belajar serta rendahnya hasil belajar siswa, hal ini dapat dilihat pada data sebelumnya. 
Hasil belajar siswa pada siklus II ternyata hasilnya cukup baik, hal ini dapat dilihat dari banyaknya siswa yang sudah memahami materi rangkaian listrik, sebagian besar dari siswa kelas IX-3 sudah mencapai nilai ketuntasan belajar ( di atas 75 ). Jumlah siswa yang mencapai ketuntasan sebanyak 33 orang siswa menunjukkan pencapaian yang sangat signifikan walaupun masih ada 3 orang siswa lagi yang belum mencapai ketuntasan, menurut peneliti hal ini disebabkan kurang aktifnya siswa tersebut.

Berdasarkan hasil penelitian berupa kegiatan awal, kegiatan lanjutan berupa tindakan pada siklus I dan siklus II dalam proses pembelajaran dengan menggunakan metode eksperimen, ternyata telah diperoleh peningkatan hasil belajar yang sangat signifikan. Hal ini dapat dilihat dari meningkatnya nilai Persentase Ketuntasan Klassikal (PKK) serta nilai rata-rata hasil belajar siswa. Hasil tes siklus II ternyata nilai PKK yang diperoleh siswa kelas IX-3 SMP Negeri 1 Percut Sei Tuan TP.2017-2018 telah mencapai 91,67\%. Apabila nilai PKK lebih besar dari $85 \%$ maka telah tercapai ketuntasan belajar

\section{KESIMPULAN}

Dari hasil pembahasan yang sudah diuraikan dalam bab IV sebelumnya, maka peneliti dapat menarik kesimpulan bahwa Penggunaan metode Eksperimen pada materi rangkaian listrik dapat meningkatkan minat dan hasil belajar IPA siswa kelas IX-3 SMP N1 Percut Sei Tuan. dengan data sebagai berikut : Hasil pengamatan minat belajar Pad siklus I rata-rata $62,31 \%$, setelah dilakukan perbaikan pada siklus II, terjadi peningkatan minat belajar sebesar $76,10 \%$ dan Pada siklus kesatu rata-rata hasil belajar IPA adalah $63,89 \%$ sedangkan pada siklus kedua rata-rata hasil belajar
Matematika adalah $91,67 \%$ berarti mengalami kenaikan secara signifikan

\section{UCAPAN TERIMAKASIH}

Peneliti mengucapkan banyak terimakasih kepada kepala sekolah dan rekan sejawad guru SMPN 1 Percut Sei tuan yang ikut berpartisifasi dalam menyelesaikan penelitian tindakan kelas ini.

\section{DAFTAR PUSTAKA}

Dahar, R.W. (2006). Teori-Teori Belajar dan Pembelajaran. Bandung: Erlangga

Dimyati dan Mujiono. (2002) Belajar dan Pembelajaran, Jakarta: Reneka Cipta

Depdiknas. (2006). Kurikulum Tingkat Satuan Pendiddikan Mata Pelajaran Ilmu Pengetahuan Alam. Jakarta: Depdiknas.

Departemen Pendidikan Nasional. (2003). Standar Kompetensi Mata Pelajaran Fisika Sekolah Menengah Atas dan Aliyah. Jakarta: Departemen Pendidikan Nasional.

Direktorat Jendral Pendidikan Dasar dan Menengah. (2003). Pedoman Khusus Pengembangan Silabus dan Penilaian Mata Pelajaran Fisika. Jakarta: Direktorat Jendral Pendidikan Dasar dan Menengah.

Direktorat Jendral Pendidikan Dasar dan Menengah. (2003). Pedoman Umum Pengembangan Sistem Penilaian Hasil Belajar Berbasis Kompetensi Siswa Sekolah Menengah Pertama (SMP). Jakarta: Direktorat Jendral Pendidikan Dasar dan Menengah.

Direktorat Jendral Pendidikan Dasar dan Menengah. (2004). Sistem Penilaian Kurikulum 2004. Jakarta: Direktorat Jendral Pendidikan Dasar dan Menengah.

Hermawan,A.H. (2007) Belajar dan Pembelajaran SD. Bandung: UPI Press

Irawan, R. (2002). Asesmen Kinerja Siswa dalam Praktikum Mikroorganisme Kolam. Skripsi: FPMIPA UPI Bandung: Tidak diterbitkan.

Mahmudah, S. (2000). Penerapan Penilaian Kinerja (Performance Assessment) Pada Pembelajaran Subkonsep Jaringan Hewan (Penelitian Tindakan Kelas di MAN Yokyakarta). Tesis: PPs. UPI Bandung: Tidak diterbitkan.

Purwanto. (2010) Evaluasi Hasil Belajar, (Yogyakarta:Pustaka Belajar), 42 
Yohana / Jurnal Pendidikan Biologi 9 (3) (2020) 40 - 48

Roestiyah, N.K (2012). Strategi Belajar Mengajar. Jakarta: Renika Cipta

Sagala, S. (2012) Konsep dan Makna Pembelajaran. Bandung:Alfabeta

Sanjaya, Wina. 2008. Strategi pembelajaran berorentasi Standar Proses Pendidikan. Jakarta; Kencana Perdana media group.
Sudjana.N dan Ibrahim, (2009). Penelitian dan Penilaian Pendidikan Bandung: Sinar Baru Algesindo 